\title{
PENGOLAHAN DATA STATISTIK DENGAN MENGGUNAKAN PROGRAM MINITAB
}

FAURANI SANTI SINGAGERDA

2014 


\section{MODUL 1 \\ PENGENALAN MINITAB}

Tujuan Praktikum :

Memperkenalkan beberapa operasi dari paket perangkat lunak Minitab .

Setelah Anda membuka program Minitab di komputer Anda, di layar akan terlihat dua kotak yang terpisah satu sama lain. Kotak yang berada di bagian atas dinamakan kotak Session sedangkan kotak yang berada di bagian bawah dinamakan kotak Data .

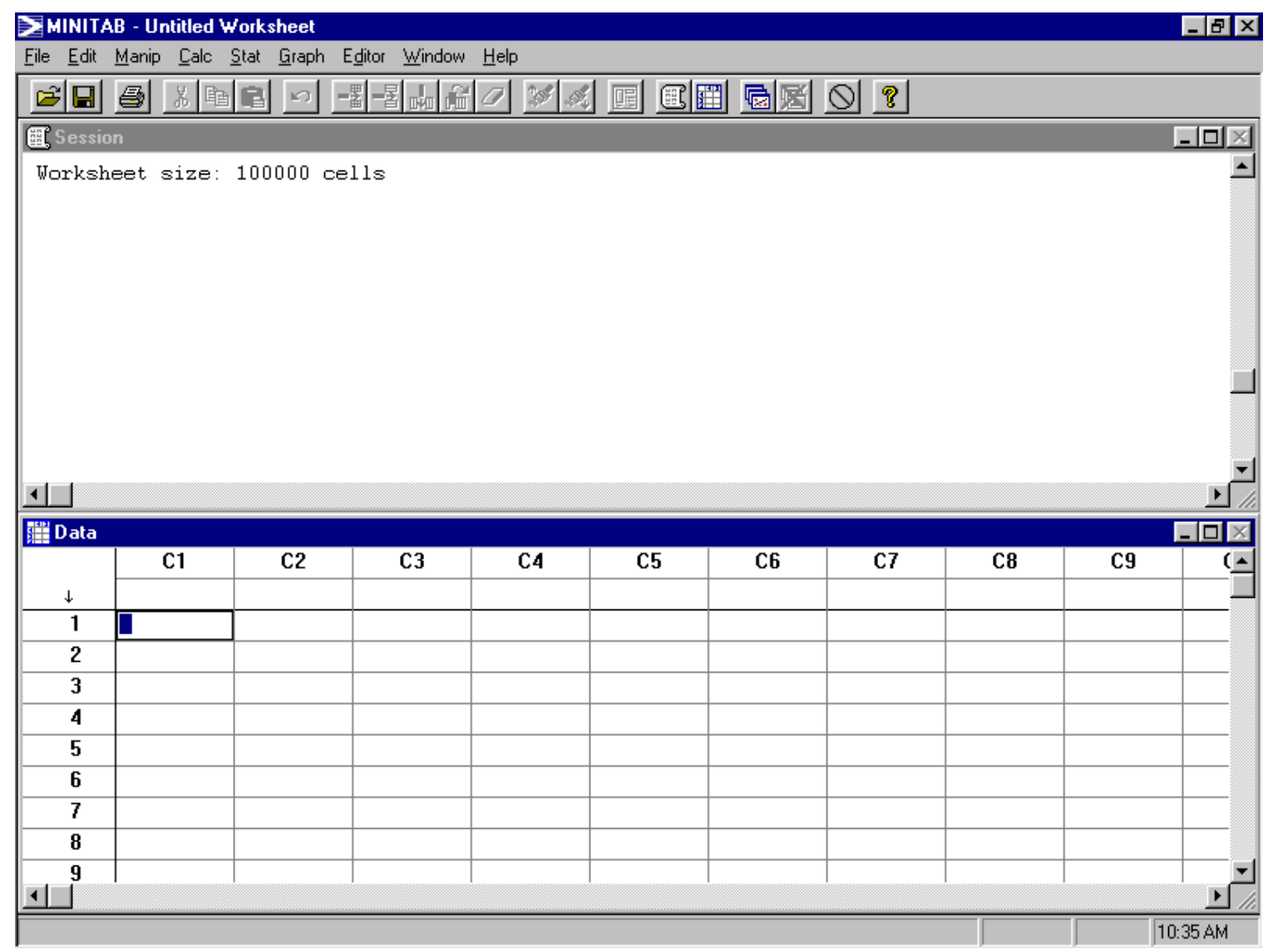

Sekarang coba Anda klik kursor pada kotak Session. Lalu pada Menu pilih Editor dan klik Enable Command Language. Perintah Enable Command Language ini berfungsi agar kita dapat melihat setiap perintah yang kita ajukan pada data yang akan diproses dan perintah ini akan muncul di kotak Session.

Kemudian Anda coba ambil 10 data acak dan simpanlah di kolom data C1 yaitu dengan cara: dari Menu Calc lalu pilih Random Data dan klik Normal (hanya 
sebagai contoh). Lalu perintahkan Generate 10 rows of data, Store in column(s) : C1 dan klik OK.

\section{$\underline{\text { Menu Pada Minitab }}$}

\section{Manip}

a. Sort (mengurutkan data)

Misalkan : pada kolom data $\mathrm{C} 1$ urutkanlah data secara naik yaitu dari data terkecil ke data terbesar dan simpan di kolom data $\mathrm{C} 2$.

Perintah : Manip $\rightarrow$ Sort $\rightarrow$ Sort column(s) : C1 $\rightarrow$ Store sorted column(s) in : $\mathrm{C} 2 \rightarrow$ Sort by column : $\mathrm{C} 1 \rightarrow \mathrm{OK}$

b. Delete Rows (membuang sebagian atau seluruh baris data )

Misalkan : i) pada kolom data $\mathrm{C} 1$ hapuslah baris ke-1 s/d baris ke-4 .

Perintah : Manip $\rightarrow$ Delete Rows $\rightarrow$ Delete rows 1: $4 \rightarrow$ From columns : C1 $\rightarrow$ OK

Lalu ii) pada kolom data $\mathrm{C} 2$ hapuslah baris ke-2 s/d ke-5 dan juga baris ke-10 . Perintah : Manip $\rightarrow$ Delete Rows $\rightarrow$ Delete rows $2: 510 \rightarrow$ From columns : $\mathrm{C} 2 \rightarrow \mathrm{OK}$

c. Erase Variables (menghapuskan semua data pada kolom data yang diinginkan)

Misalkan : hapuslah semua data pada kolom data C1 dan C2 .

Perintah : Manip $\rightarrow$ Erase Variables $\rightarrow$ Columns, constants and matrices to erase : $\mathrm{C} 1 \mathrm{C} 2 \rightarrow \mathrm{OK}$

d. Copy Columns (membuat kopian seluruh data pada suatu kolom data ke kolom data lainnya )

Sekarang Anda coba buat lagi 10 data acak yang baru .

Perintah : Calc $\rightarrow$ Random Data $\rightarrow$ Normal ( hanya sebagai contoh ) $\rightarrow$ Generate 10 rows of data $\rightarrow$ Store in column(s) : C1 $\rightarrow$ OK

Misalkan : kopilah seluruh data pada kolom data $\mathrm{C} 1$ ke kolom data $\mathrm{C} 2$.

Perintah : Manip $\rightarrow$ Copy Columns $\rightarrow$ Copy from columns : C1 $\rightarrow$ To columns : $\mathrm{C} 2 \rightarrow \mathrm{OK}$

e. Display Data ( menampilkan semua data dari suatu kolom data yang diinginkan

pada kotak Data ke kotak Session )

Misalkan : tampilkan semua data dari kolom data C1 ke kotak Session .

Perintah : Manip $\rightarrow$ Display Data $\rightarrow$ Columns, constants and matrices to display : $\mathrm{C} 1 \rightarrow \mathrm{OK}$

\section{Calc}

a. Calculator (mengoperasikan data dengan fungsi yang diinginkan )

Misalkan : operasikan data pada kolom data $\mathrm{C} 1$ dan tentukan nilai mean-nya. Hasilnya disimpan pada kolom data $\mathrm{C} 1$.

Perintah : Calc $\rightarrow$ Calculator $\rightarrow$ Store result in variable : $\mathrm{C} 1 \rightarrow$ Functions : Statistics $\rightarrow$ Mean $\rightarrow$ Select $\rightarrow$ Expression : Mean ( C1 ) $\rightarrow$ OK

b. Column Statistics ( mengoperasikan data dengan fungsi statistik yang diinginkan)

Misalkan : operasikan data pada kolom data C2 dengan fungsi statistik standar deviasi . 
Perintah : Calc $\rightarrow$ Column Statistics $\rightarrow$ Standard deviation $\rightarrow$ Input variable : $\mathrm{C} 2 \rightarrow \mathrm{OK}$

c. Random Data ( membuat data acak )

c.1) Sample From Columns ( mengambil data sampel acak dari kolom data populasi yang telah diketahui dan tertulis di kotak data )

Misalkan : data pada kolom data C2 adalah data populasi . Ambil 5 data sampel acak dari data populasi tersebut dan simpan di kolom data C3 . Perintah : Calc $\rightarrow$ Random Data $\rightarrow$ Sample From Columns $\rightarrow$ Sample 5 rows from column(s) : C2 $\rightarrow$ Store samples in : C3 $\rightarrow$ OK Bandingkan dengan perintah : Calc $\rightarrow$ Random Data $\rightarrow$ Sample From Columns $\rightarrow$ Sample 5 rows from column(s) : C2 $\rightarrow$ Store samples in : C4 $\rightarrow$ Sample with replacement $\rightarrow$ OK

c.2) Normal Distribution ( membuat data acak yang berdistribusi normal ) Misalkan : buatlah 10 data acak yang berdistribusi normal dan simpan di kolom data C5 .

Perintah : Calc $\rightarrow$ Random Data $\rightarrow$ Normal Distribution $\rightarrow$ Generate 10 rows

of data $\rightarrow$ Store in column(s) : $\mathrm{C} 5 \rightarrow$ OK

c.3) Uniform ( membuat data acak yang seragam sesuai dengan selang yang diinginkan )

Misalkan : buatlah 10 data acak yang berdistribusi uniform dengan data terkecil adalah 1 dan data terbesar adalah 2 , lalu simpan di kolom data C6

Perintah : Calc $\rightarrow$ Random Data $\rightarrow$ Uniform $\rightarrow$ Generate 10 rows of data $\rightarrow$

Store in column(s) : C6 $\rightarrow$ lower endpoint : $1.0 \rightarrow$ upper endpoint : $2.0 \rightarrow$ OK

c.4) Binomial ( membuat data acak yang berdistribusi binomial ) dari

Misalkan : buatlah 2 kelompok kolom data yang masing - masing terdiri

10 data acak yang berdistribusi binomial dengan jumlah percobaan adalah 200 dan peluang sukses terjadi adalah 0,991 . Kemudian simpan data tersebut

di kolom data $\mathrm{C} 7$ dan $\mathrm{C} 8$.

Perintah : Calc $\rightarrow$ Random Data $\rightarrow$ Binomial $\rightarrow$ Generate 10 rows of data $\rightarrow$

Store in column(s) : C7 C8 $\rightarrow$ Number of trials : $200 \rightarrow$ Probability of success : $0.991 \rightarrow$ OK

c.5) Probability Distributions ( akan dibahas tersendiri pada modul selanjutnya )

\section{Stat}

a. Basic Statistics

a.1) Descriptive Statistics ( menampilkan sekilas gambaran fungsi statistik dari

data yang diinginkan )

Misalkan : tampilkan sebagian fungsi statistik dari kolom data C7 . 
C7

Perintah : Stat $\rightarrow$ Basic Statistics $\rightarrow$ Descriptive Statistics $\rightarrow$ Variables :

$$
\rightarrow \text { OK }
$$

Mengenai submenu Basic Statistics ini akan dibahas secara mendalam pada modul - modul selanjutnya .

b. Tables

b.1) Tally ( menampilkan frekuensi data yang muncul dari suatu kolom data ) Misalkan : tampilkan frekuensi kolom data C8 .

Perintah : Stat $\rightarrow$ Tables $\rightarrow$ Tally $\rightarrow$ Variables : C $8 \rightarrow$ Display ( Counts , c. EDA

Percents , Cumulative counts , Cumulative percents ) $\rightarrow$ OK

c.1) Stem and Leaf (menampilkan batang dan daun dari suatu kolom data ) Misalkan : tampilkan batang dan daun dari kolom data C7 setiap penambahan puluhan .

10

Perintah : Stat $\rightarrow$ EDA $\rightarrow$ Stem and Leaf $\rightarrow$ Variables : C7 $\rightarrow$ Increment :

$\rightarrow \mathrm{OK}$

c.3) Boxplot ( menampilkan kotak plot dari suatu kolom data )

Misalkan : tampilkan boxplot dari kolom data C8 .

Perintah : Stat $\rightarrow$ EDA $\rightarrow$ Boxplot $\rightarrow$ Graph ( pada Y1 isi C8 ) $\rightarrow$ OK

Hasil dari perintah boxplot di atas akan muncul pada kotak yang baru .

\section{Graph}

a. Histogram ( menampilkan diagram batang dari suatu kolom data )

Misalkan : tampilkan histogram dari kolom data C8 .

Perintah : Graph $\rightarrow$ Histogram $\rightarrow$ Graph variables : pada graph X1 isi C8 $\rightarrow$ OK

Hasil dari perintah histogram di atas akan muncul pada kotak yang baru .

b. Character Graphs

\section{b.1) Histogram}

Misalkan : tampilkan histogram dari kolom data C8 .

$\mathrm{OK}$

Perintah : Graph $\rightarrow$ Character Graphs $\rightarrow$ Histogram $\rightarrow$ Variables : C8 $\rightarrow$

Hasil dari perintah histogram ini akan muncul pada kotak Session . Untuk ini

memudahkan pengamatan antara kotak Data dan kotak Session, perintah

lebih efektif untuk digunakan .

\section{b.2) Boxplot}

Misalkan : tampilkan boxplot dari kolom data C8 .

Perintah : Graph $\rightarrow$ Character Graphs $\rightarrow$ Boxplot $\rightarrow$ Variables : C8 $\rightarrow$ OK Hasil dari perintah boxplot ini akan muncul pada kotak Session . Untuk memudahkan pengamatan antara kotak Data dan kotak Session , perintah ini

lebih efektif untuk digunakan .

b.3) Scatter Plot ( menampilkan suatu plot antara 2 kolom data yang akan diamati )

Misalkan : tampilkan scatter plot antara kolom data C7 dan C8 dengan C8 adalah variabel pada absis . 
Perintah : Graph $\rightarrow$ Character Graphs $\rightarrow$ Scatter Plot $\rightarrow$ Y variable : C7 $\rightarrow$ $\mathrm{X}$ variable : $\mathrm{C} 8 \rightarrow \mathrm{OK}$

\section{$\underline{\text { Latihan }}$}

Buatlah 100 data acak ( berdistribusi Normal , Uniform atau Binomial ) dan simpanlah di $\mathrm{C} 1$. Untuk data acak yang berdistribusi Binomial, jumlah percobaan adalah 1000 dan peluang sukses terjadi adalah 0,75 .

a. Urutkanlah data acak tersebut secara naik dan simpan di C2 !

b. Hapuslah semua data $\mathrm{C} 1$, kemudian kopilah semua data $\mathrm{C} 2 \mathrm{ke} \mathrm{C} 1$ !

c. Tampilkan semua data C1 ke kotak Session!

d. Operasikan C1 dengan fungsi Sum of Squares dan simpan di C3, kemudian tentukan

juga Rangenya !

e. Misalkan $\mathrm{C} 1$ sebagai data populasi, buatlah :

e.i. 50 data sampel acak dari $\mathrm{C} 1$ dan simpan di $\mathrm{C} 4$

e.ii.50 data sampel acak dari $\mathrm{C} 1$ dan simpan di C5 dengan syarat bahwa sampel yang

diambil boleh diulang

f. Tampilkan sebagian fungsi statistik $\mathrm{C} 4$ dan $\mathrm{C} 5$ !

g. Tampilkan frekuensi dari C4 dan C5 !

h. Tampilkan batang dan daun dari C4 dan C5 ! Untuk data yang berdistribusi Binomial

memakai penambahan puluhan, sedangkan untuk data yang berdistribusi Normal dan

Uniform tidak memakai penambahan .

i. Tampilkan Boxplot dan Histogram dari C4 dan C5 ! ( muncul pada kotak baru )

j. Tampilkan Boxplot dan Histogram dari C4 dan C5 ! ( muncul pada kotak Session )

k. Tampilkan Scatter Plot dari C4 dan C5, dengan C4 sebagai ordinatnya !

Untuk semua perintah di atas, Anda diharapkan untuk mencoba mengamati dan menganalisa setiap hasil keluaran dari setiap perintah yang dilakukan . 


\section{MODUL 2}

\section{MENGGAMBARKAN DATA}

Tujuan Praktikum:

Mahasiswa/i dapat menganalisa dan menyimpulkan setiap hasil dari data-data yang diberikan dalam distribusi frekuensi, distribusi frekuensi relatif, distribusi frekuensi kumulatif, boxplot, histogram dan stem and leaf

1. Masukkan data harga-harga mobil mewah yang terjual pada bulan Agustus di USA (dalam US\$) ke kotak data minitab. Simpan di kolom data C1 dengan nama harga.

\begin{tabular}{|llllllllll|}
\hline 20197 & 20372 & 17454 & 20591 & 23651 & 24453 & 14266 & 15021 & 25683 & 27872 \\
16587 & 20169 & 32851 & 16251 & 17047 & 21285 & 21324 & 21609 & 25670 & 12546 \\
12935 & 16873 & 22251 & 22277 & 25034 & 21533 & 24443 & 16889 & 17004 & 14357 \\
17155 & 16688 & 20657 & 23613 & 17895 & 17203 & 20765 & 22783 & 23661 & 29277 \\
17642 & 18981 & 21052 & 22799 & 12794 & 15263 & 32925 & 14399 & 14968 & 17356 \\
18442 & 18722 & 16331 & 19817 & 16766 & 17633 & 17962 & 19845 & 23285 & 24896 \\
26076 & 29492 & 15890 & 18740 & 19374 & 21571 & 22449 & 25337 & 17642 & 20613 \\
21220 & 27655 & 19442 & 14891 & 17818 & 23237 & 17445 & 18556 & 18639 & 21296 \\
\hline
\end{tabular}

a. Urutkan data tersebut dan simpan di kolom data C2.

b. Tentukan nilai maksimum dan minimumnya dan tuliskan hasilnya di kotak session!

c. Buatlah distribusi frekuensinya! Analisa dan beri kesimpulan!

d. Buatlah Boxplotnya! Analisa dan beri kesimpulan!

e. Buatlah histogramnya! Analisa dan beri kesimpulan!

f. Bandingkan Boxplot yang terbentuk pada (d) dan histogram yang terbentuk pada (e)! Analisa dan beri komentar!

g. Apabila 10 data pertama dan 5 data terakhir dari data harga pada kolom $\mathrm{C} 1$ di atas dihilangkan (data baru disimpan di C3), bagaimana bentuk boxplot dan histogram yang terbentuk sebelumnya.

2. Masukkan data jumlah kolom iklan yang terjual selama tahun 2002 oleh anggotaanggota dari asosiasi distributor mobil di Italia ke kotak data minitab. Simpan di kolom data $\mathrm{C} 4$ dengan nama iklan.

\begin{tabular}{|rrrrrrrrrrrr|}
\hline 96 & 93 & 88 & 117 & 127 & 95 & 113 & 96 & 108 & 94 & 148 & 156 \\
139 & 142 & 94 & 107 & 125 & 155 & 155 & 103 & 112 & 127 & 117 & 120 \\
112 & 135 & 132 & 111 & 125 & 104 & 106 & 139 & 134 & 119 & 97 & 89 \\
118 & 136 & 125 & 143 & 120 & 103 & 113 & 124 & 138 & & & \\
\hline
\end{tabular}
a. Urutkan data tersebut dan simpan di kolom data C5.
b. Tentukan nilai maksimum dan minimumnya dan tuliskan hasilnya di kotak session!
c. Buatlah distribusi frekuensinya! Analisa dan beri kesimpulan!
d. Buatlah Boxplotnya! Analisa dan beri kesimpulan!
e. Buatlah histogramnya! Analisa dan beri kesimpulan! 
f. Buatlah Stem and Leafnya! Analisa dan beri kesimpulan!

3. Masukkan data Baseball 98 yang melaporkan informasi tentang 30 tim liga basket utama pada tahun 1998 pada lampiran ke kotak data minitab (hanya data pendapatan tim (team salary)). Simpan di kolom data C6 dengan nama pendapatan.

(data halaman 521 Basic Statistics)

a. Urutkan data tersebut dan simpan di kolom data C7.

b. Tentukan nilai maksimum dan minimumnya dan tuliskan hasilnya di kotak session!

c. Buatlah distribusi frekuensinya! Analisa dan beri kesimpulan!

d. Apakah ada pendapatan tim yang merupakan pencilan? Jelaskan!

e. Berdasarkan distribusi pada c, buatlah distribusi frekuensi kumulatifnya!

f. Berdasarkan e:

- Berapa persen dari semua tim yang mempunyai pendapatan kurang dari US\$35 juta?

- Berapa tim yang mempunyai pendapatan kurang dari US\$ 50 juta?

- Berapa tim yang mempunyai pendapatan kurang dari US\$25 juta?

g. Buatlah Boxplotnya! Analisa dan beri kesimpulan!

h. Buatlah histogramnya! Analisa dan beri kesimpulan!

i. Buatlah Stem and Leafnya! Analisa dan beri kesimpulan!

Cara membuat daftar distribusi frekuensi data berkelompok:

1. Urutkan data dari terkecil ke terbesar. Tentukan jangkauannya yaitu $\mathbf{J}=$ nilai $\max$ - nilai min.

2. Tentukan banyak kelas (k) yaitu $k=13,3 \log n$ dengan $n$ jumlah data.

3. Tentukan panjang kelas yaitu $p=j / k$. Biasanya $p$ dipilih bilangan ganjil agar titiktitik tengah kelas merupakan bilangan yang baik.

4. Atur datanya agar termuat dalam banyak kelas dan panjang kelas yang telah ditentukan. Nilai min biasanya sebagai batas bawah kelas pertama.

5. Tentukan frekuensi tiap kelas. 


\section{MODUL 3 \\ MENGGAMBARKAN DATA (2)}

Tujuan Praktikum:

Mahasiswa/i dapat menganalisa dan menyimpulkan setiap hasil dari data-data yang diberikan dalam boxplot dan descriptive statistics.

1. Lihat data Real Estate pada lampiran no 1 yang mengimformasikan tentang rumah yang terjual di Florida tahun lalu.

a. Masukkan data Selling Price ke kotak data minitab dan simpan di kolom data C1 dengan nama harga jual.

- Hitunglah rata-rata, median dan standar deviasi!

- Tentukan harga jual terbesar, terkecil, kuartil bawah dan kuartil atasnya!

- Buatlah boxplot dan amati hasilnya! Analisa dan beri kesimpulan!

- Berapa persenkah harga jual yang terletak diantara kuartil bawah dan kuartil atasnya?

b. Masukkan data area of the home in square feet ke kotak data minitab dan simpan di kolom $\mathrm{C} 2$ dengan nama area.

- Hitunglah rata-rata, median dan standar deviasi!

- Tentukan area terbesar, terkecil, kuartil bawah dan kuartil atasnya!

- Buatlah boxplot dan amati hasilnya! Analisa dan beri kesimpulan!

2. Lihat data Baseball 98 pada lampiran no 2 yang mengimformasikan tentang 30 tim liga basket utama pada tahun 1998.

a. Masukkan data team salary ke kotak data minitab dan simpan di kolom data

C3 dengan nama pendapatan.

- Hitunglah rata-rata, median dan standar deviasi!

- Buatlah boxplot dan laporkan bagaimana distribusi dari pendapatan timtim tersebut?

b. Masukkan data years ke kotak data minitab dan simpan di kolom C4 dengan nama tahun.

- Hitunglah rata-rata, median, kuartil dan standar deviasi!

- Buatlah boxplotnya dan bero laporan dari hasil boxplot tersebut! Apakah ada data yang merupakan pencilan?

3. Lihat data OECD pada lampiran no 3 yang mengimformasikan data sensus ekonomi dan bisnis untuk 29 negara. Masukkan data percent of the population over the age of 65 ke kotak data minitab dan simpan di kolom C5 dengan nama persen.

- Hitunglah rata-rata, median, kuartil dan standar deviasi!

- Buatlah boxplotnya dan beri laporan dari hasil boxplot tersebut! Apakah ada data yang merupakan pencilan?

- Negara mana saja yang mempunyai populasi di atas 65 tahun yang kurang dari 6,5 persen? 
MODUL 4

\section{DISTRIBUSI VARIABEL ACAK DISKRET}

Tujuan Praktikum:

Mahasiswa/i dapat memahami dan menganalisa sifat-sifat dari distribusi Bernoulli, Binomial dan Poisson.

\section{Distribusi Bernoulli}

Variabel acak Bernoulli memiliki nilai $\mathrm{x}=1$ jika percobaan sukses dan $\mathrm{x}=0$ jika percobaan gagal. Peluang untuk sukses dinyatakan oleh $\mathrm{p}$ dan peluang gagal dinyatakan oleh 1-p. Mean dari distribusi Bernoulli adalah p sedangkan variansinya adalah $\mathrm{p}(1-\mathrm{p})$.

Misalkan dilakukan 25 kali percobaan yang menghasilkan percobaan gagal dan sukses dengan peluang sukses $(\mathrm{x}=1)$ adalah 0,3 . Data disimpan pada kotak $\mathrm{C} 1$.

Pada menu Calc pilih submenu Random Data kemudian pilih Bernoulli....

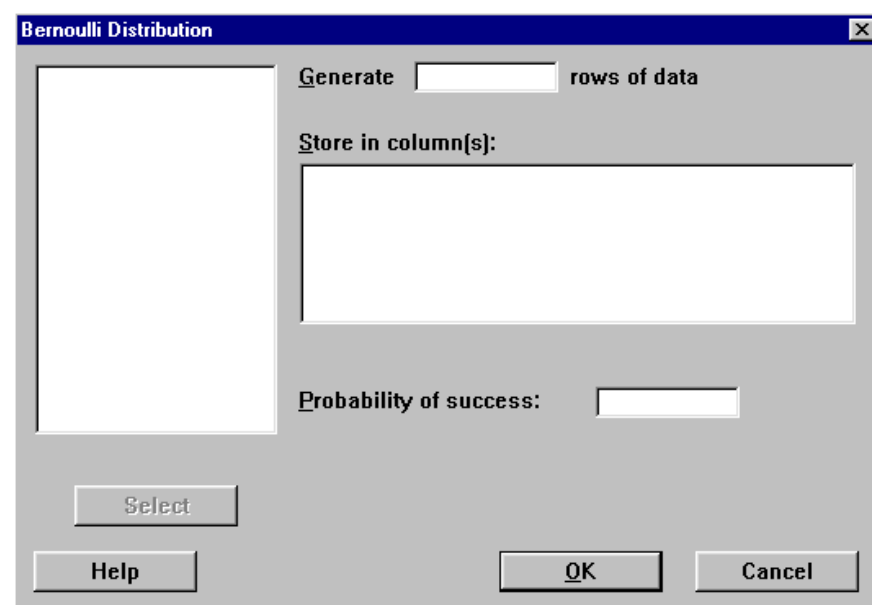

Untuk kotak Generate isi 25, kotak Store in column(s) ketik C1 dan Probability of success isi 0.3 .

Atau dengan perintah alternatif:

MTB > note distribusi bernoulli

$\mathrm{MTB}>$ random $25 \mathrm{c} 1$;

SUBC $>$ bernoulli 0.3.

MTB >print $\mathrm{c} 1 \quad \rightarrow$ untuk menampilkan data di kotak session

Hasil C1 akan tampak di kotak Session.

Kemudian Pada menu Stat pilih submenu Tables kemudian pilih Tally....: 


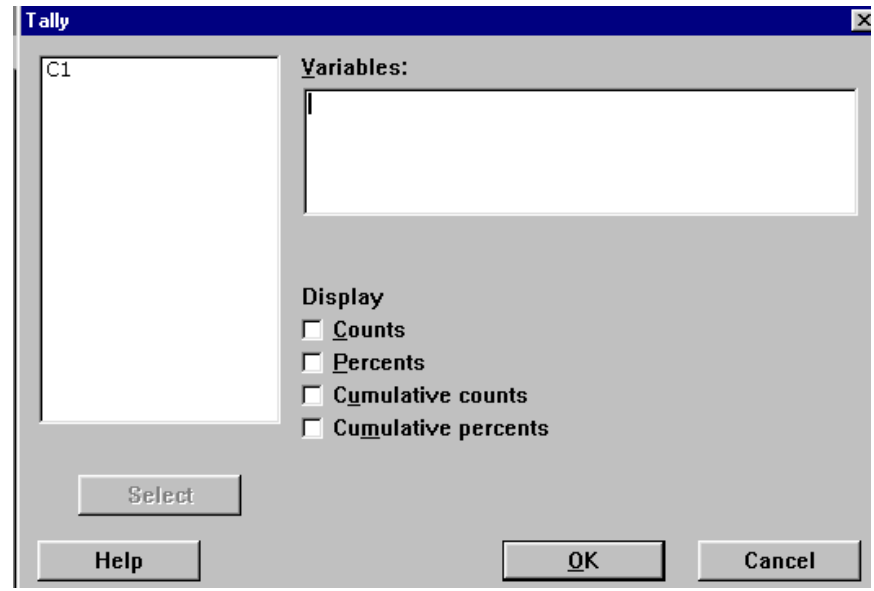

Pada kotak Variables: masukkan $\mathrm{C} 1$ dengan cara mengklik select dan untuk Display klik Counts dan Percents kemudian klik OK.

Atau dengan perintah alternatif:

MTB > tally c1;

SUBC > count;

$\mathrm{SUBC}>$ percent.

Tugas:

1. Berapa kali percobaan sukses dan berapa kali percobaan gagal dalam kasus di atas?

2. Lakukan 50 kali percobaan yang menghasilkan percobaan sukses dan gagal dengan peluang gagal $(\mathrm{x}=0)$ sebesar $40 \%$, kemudian hitunglah berapa kali percobaan yang menghasilkan sukses dan berapa kali percobaan yang menghasilkan gagal?

$\mathrm{n}$ menyatakan banyaknya percobaan, $\mathrm{x}$ menyatakan banyaknya percobaan yang menghasilkan sukses (dari $\mathrm{n}$ percobaan), $\mathrm{p}$ menyatakan peluang percobaan sukses dan 1-p menyatakan peluang percobaan gagal.

Di sini kita akan melihat karakteristik dari distribusi binomial melalui pengamatan terhadap fungsi distribusi peluang diskretnya.

Misalkan kita akan mengamati fungsi distribusi peluang (pdf) binomial untuk $\mathrm{n}=5$ dengan peluang percobaan sukses adalah 0,1 .

Pada menu Calc pilih submenu Make Patterned Data kemudian pilih submenu Simple Set of Numbers...:

Maka akan tampil: 


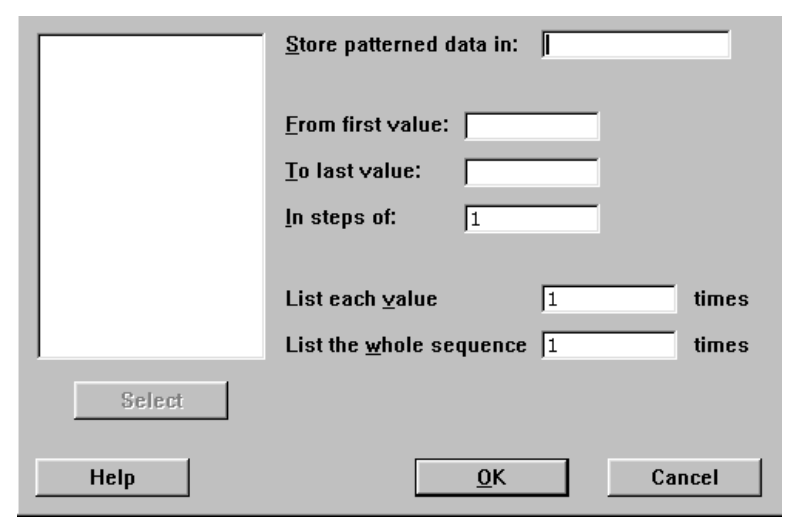

kotak Stored patterned data in isi C2, dengan first value 0 dan last value 5.

Atau dengan perintah alternatif:

MTB > set c2 \{membuat data set bilangan bulat 0-5

DATA $>0: 5$

DATA $>$ end.

MTB > print c2

Hasil C2 akan tampak di kotak session.

Kemudian pada menu Calc pilih submenu Probability Distributions kemudian pilih Binomial:

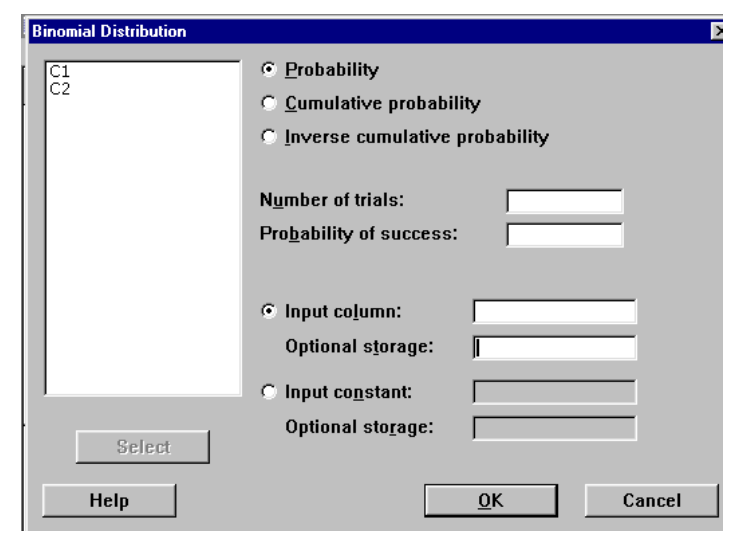

Pilih Probability, Number of trials: isi dengan 5 Probability of success: isi dengan 0.1 dan input column isi dengan $\mathrm{C} 2$ dan optional storage dengan $\mathrm{C} 3$

Atau dengan perintah alternatif:

MTB > pdf c2 c3;

SUBC $>$ binomial 50.1 . \{distribusi peluang untuk $\mathrm{n}=5$ dan $0=0,1\}$

Tugas:

1. Berapa peluang percobaan gagal semua?

2. Berapa peluang percobaan menghasilkan hanya satu kali sukses?

3. Lakukan percobaan untuk nilai $\mathrm{p}=0,3,0,5$ dan 0,9 untuk melihat pdf distribusi binomial untuk $\mathrm{n}=100$, kemudian beri komentar hasil yang diperoleh! 
pada menu Calc pilih submenu Probability Distributions kemudian pilih Binomial:



Pilih Cumulative Probability, Number of trials: isi dengan 5 Probability of success: isi dengan 0.1 dan input column isi dengan $\mathrm{C} 2$ dan optional storage dengan C4

Atau dengan perintah alternatif:

Contoh perintah fungsi distribusi kumulatif (cdf) untuk distribusi binomial:

MTB > cdf c2 c4;

SUBC > binomial 50.1 .

Akan muncul di kotak Session hasil berikut:

$\begin{array}{cc}\text { Binomial with } \mathrm{n}=5 \text { and } \mathrm{p}=0.100000 \\ \mathrm{x} & \mathrm{P}(\mathrm{x}<=\mathrm{x}) \\ 0.00 & 0.5905 \\ 1.00 & 0.9185 \\ 2.00 & 0.9914 \\ 3.00 & 0.9995 \\ 4.00 & 1.0000 \\ 5.00 & 1.0000\end{array}$

Dari hasil tersebut dapat disimpulkan bahwa jika kita melakukan 5 kali percobaan yang masing-masing dapat menghasilkan sukses atau gagal dengan peluang setiap percobaan sukses $10 \%$, maka peluang semua percobaan gagal adalah 0,5905 . Peluang percobaan menghasilkan paling banyak 1 kali sukses adalah 0,9185 dan seterusnya.

Tugas:

Lakukan percobaan untuk nilai $\mathrm{p}=0,2,0,6$ dan 0,8 untuk melihat cdf distribusi binomial untuk $n=50$. Kemudian beri komentar terhadap hasil yang Anda peroleh.

Di sini $\lambda$ menyatakan rata-rata banyaknya peristiwa dalam suatu selang waktu dan $\mathrm{x}$ menyatakan banyaknya peristiwa dalam selang waktu tertentu.

Sedangkan $\mathrm{p}(\mathrm{x})$ menyatakan peluang terjadinya $\mathrm{x}$ peristiwa dalam selang waktu tertentu dengan diketahui rata-rata peristiwa yang terjadi pada selang waktu tersebut adalah $\lambda$. 
Misalkan kita akan mengamati fungsi distribusi peluang untuk distribusi Poisson dengan $\lambda=0,1$.

MTB > pdf c2 c5;

SUBC $>$ poisson 0.1 .

Tugas:

1. Berapa persen peluang untuk kasus $\lambda=0,1$ di atas bahwa peristiwa tersebut tidak terjadi sama sekali dan berapa persen untuk peluang terjadi satu peristiwa?

2. Lakukan percobaan untuk nilai $\lambda=0,5,2$ dan 5 untuk menampilkan pdf nya. Kemudian amati dan beri komentar!

Contoh perintah fungsi distribusi kumulatif untuk distribusi poisson:

MTB > cdf c2 c6;

SUBC $>$ poisson 0.1 .

Akan muncul di kotak session hasil berikut:

Poisson with $\mathrm{mu}=3.00000$

$\begin{array}{cc}x & P(X<=x) \\ 0.00 & 0.0498 \\ 1.00 & 0.1991 \\ 2.00 & 0.4232 \\ 3.00 & 0.6472 \\ 4.00 & 0.8153 \\ 5.00 & 0.9161\end{array}$

Tugas:

Lakukan percobaan untuk nilai $\lambda=0,3,1$ dan 3 untuk menampilkan cdf-nya. Kemudian amati dan beri komentar hasil yang diperoleh.

Tigas:

1. Buat 500 sampel acak berdistribusi Binomial dengan peluang sukses $p=0,2$ ( simpan di C4) dan peluang sukses $p=0,5$ (simpan di C5). Kemudian buatlah distribusi frekuensi dan histogram untuk C4 dan C5.

2. Buat 500 sampel acak berdistribusi Poisson dengan mean $\lambda=50$ (simpan di C6) dan mean $\lambda=100$ (simpan di C7). Kemudian buatlah distribusi frekuensi dan histogram untuk C6 dan C7.

3. Bandingkan histogram C4-C6 dan histogram C5-C7! Apakah identik? 


\section{MODUL 5}

\section{DISTRIBUSI NORMAL}

\section{TUJUAN PRAKTIKUM:}

Mahasiswa/i dapat memahami beberapa sifat distribusi normal melalui pengamatan terhadap distribusi normal dengan menggunakan alat-alat statistika eksplorasi.

Distribusi normal adalah distribusi kontinyu yang paling populer, karena sebagian besar uji statistika yang dipergunakan memanfaatkan asumsi distribusi ini. Ciri-ciri distribusi normal yaitu memiliki puncak tunggal, simetri dan memiliki bentuk setangkup (seperti lonceng).

Bentuk grafik dari distribusi normal bergantung pada dua parameter yaitu mean (pusat) dan varian (sebaran).

dengan $-\infty<\mathrm{x}<\infty$. Fungsi ini biasa disebut sebagai fungsi kepadatan peluang distribusi normal.

Misalkan kita akan membuat data antara -15 s/d 15 dengan selisih antar data 0,1 satuan dan disimpan di C1. Perintah pada kotak Session:

Pada menu Calc pilih submenu Make Patterned Data kemudian pilih submenu Simple Set of Numbers...:

Maka akan tampil:

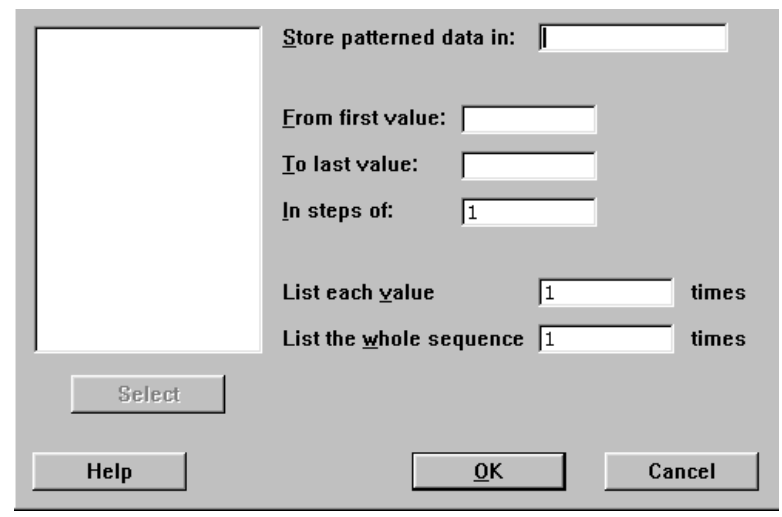

kotak Stored patterned data in isi $\mathrm{C} 1$, dengan first value -15 dan last value 15 kemudian in steps of isi dengan 0.1 .

Atau dengan perintah alternatif:

MTB> set c1

DATA> $>15: 15 / 0.1$

DATA $>$ end.

Hasil akan muncul pada C1.

Kemudian untuk membuat data berdistribusi normal dengan mean $=0$ dan varian $=1$ yang terletak pada interval [-15, 15], kita ketikkan perintah berikut: 
Kemudian pada menu Calc pilih submenu Probability Distributions kemudian pilih Normal:

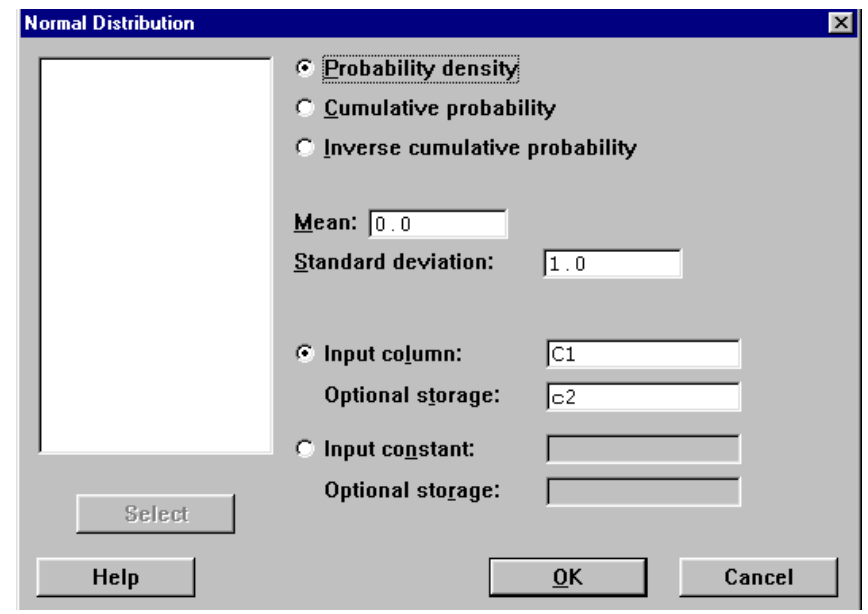

atau,

MTB> pdf c1 c2;

SUBC> normal 0.01 .0 .

Tugas : Amati hasil yang muncul pada C1 dan C2. Beri komentar!

Untuk pengamatan secara eksplorasi data yang diambil secara acak dari populasi berdistribusi normal dengan mean $=0$ dan varian $=1$, maka kita akan mencoba mengambil 25 data dan mengamati hasil yang diperoleh dengan memanfaatkan alat statistika eksplorasi yang telah kita kenal.

Kemudian pada menu Calc pilih submenu Random Data kemudian pilih Normal:

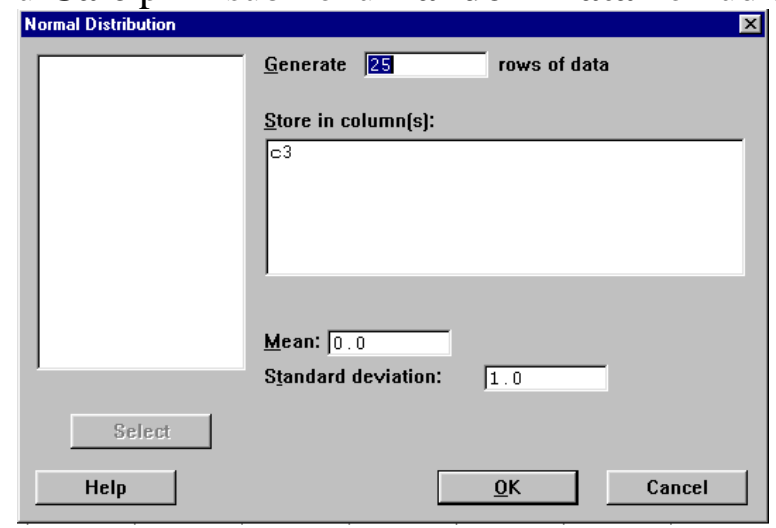

Perintah pada kotak Session:

MTB> random $25 \mathrm{c} 3$;

SUBC> normal 0.01 .0 .

$\mathrm{MTB}>$ print $\mathrm{c} 3$

Kemudian tulis perintah berikut dan amati hasil dari perintahnya yang memanfaatkan alat statistika eksplorasi data yang telah kita pelajari sebelumnya.

MTB> histo c3 (membuat histogram dari data c3)

MTB $>$ stem c3 (membuat stem and leaf dari data c3)

MTB > boxp c3 (membuat boxplot dari data c3) 
MTB> nscore c3 c4 (kalkulasi normal score dari c3, disimpan di c4)

MTB> corr c3 c4 (menghitung korelasi antara c3 dan c4)

Tugas: Beri penjelasan pada setiap hasil dari perintah di atas.

Jika nilai korelasi antara c3 dan c4 lebih besar dari 0,9662 (nilai 0,9662 adalah uji normal data dengan korelasi untuk $\mathrm{n}=25$ dan tingkat kepercayaan $=90 \%$ ), maka dapat disimpulkan bahwa untuk tingkat kepercayaan $90 \%$ data tersebut berdistribusi normal. Jadi dapat dikatakan bahwa data dengan korelasi mendekati satu memiliki distribusi mendekati distribusi normal.

\section{Tugas:}

1. Lakukan pengamatan secara eksplorasi untuk 50 data yang diambil secara acak dari populasi berdistribusi normal dengan mean $=0$ dan varian $=1$. Kemudian lakukan kegiatan seperti pada pengambilan 25 data acak. Apakah untuk tingkat kepercayaan $95 \%$ data tersebut berdistribusi normal atau tidak? (untuk $\mathrm{n}=50$ dan $\alpha$ $=5 \%$, nilai uji normal data dengan korelasi $=0,9764$ ).

2. Lakukan pengamatan secara eksplorasi untuk 1000 data yang diambil secara acak dari populasi berdistribusi normal dengan mean $=0$ dan varian $=1$. kemudian lakukan kegiatan seperti pada pengambilan 25 data acak.

\section{Probability Plot}

Adalah sebuah alat untuk membantu memeriksa apakah suatu data dikatakan berasal dari distribusi tertentu atau tidak secara subjektif.

Misalkan akan dibangkitkan 50 data acak dari data berdistribusi normal dengan mean $=0$ dan varian $=1$.

Perintah: Calc/Random Data/Normal.

Lalu simpan di C9. Kemudian buat histogram dari data C9 tersebut.

Tugas: Apakah dari histogram tersebut mewakili ciri-ciri distribusi normal? Beri Penjelasan yang jelas!

Kemudian Anda buat probability plot untuk distribusi normal dari data C9.

Perintah: Graph/Probability Plot/Normal.

Tugas : Apakah dari hasil tersebut C9 dapat dikatakan berasal dari distribusi normal? Beri alasan yang jelas.

\section{Tugas :}

Dengan menggunakan Normal Probability Plot, ulangi kegiatan di atas untuk:

1. 1000 sampel acak dari populasi berdistribusi normal dengan mean=0 dan varian $=9$.

2. 500 sampel acak dari populasi berdistribusi Binomial $(100,0.5)$.

3. 50 sampel acak dari populasi berdistribusi eksponensial dengan mean=1 
MODUL 6

\section{SELANG KEPERCAYAAN}

\section{TUJUAN PRAKTIKUM:}

Mahasiswa/i dapat menganalisa dan menaksir selang kepercayaan pasar yang dapat dihasilkan dari pengamatan sejumlah data serta menyimpulkan keadaan dari analisa data yang diperoleh.

\section{Membuat Selang Kepercayaan (1- $\alpha)$ untuk mean jika $\sigma$ diketahui.}

1. Buatlah 100 data acak berdistribusi normal dengan mean $=0$ dan varians $=1$, simpan di C1. lalu buatlah selang kepercayaan $95 \%$ dari data itu dengan perintah: Stat/Basic Statistic/1-sample z (dengan memilih level 95\% dan sigma=1).

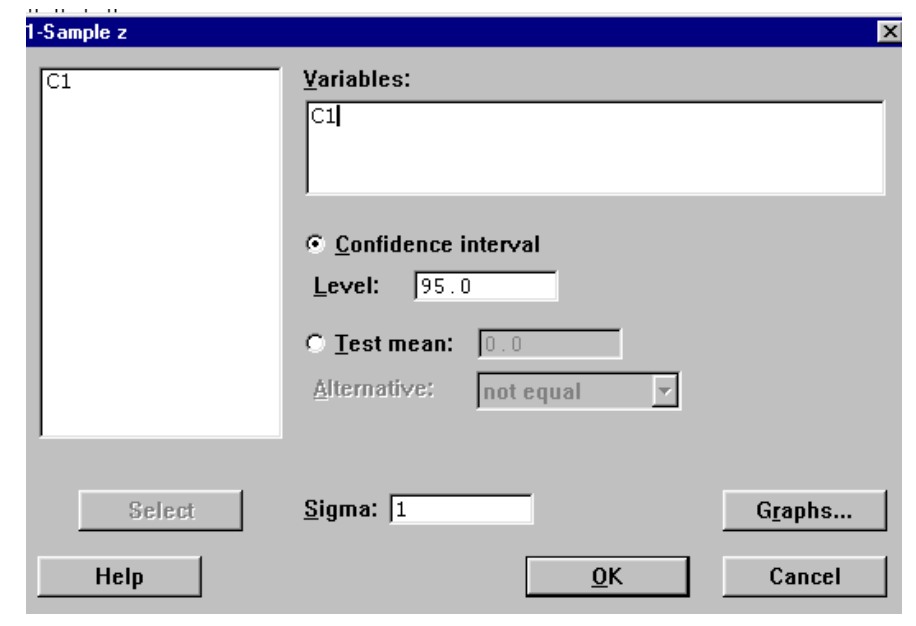

2. Buatlah selang kepercayaan $90 \%, 80 \%$, dan $75 \%$ untuk $\mathrm{C} 1$, lalu bandingkan panjang selang kepercayaan tersebut, manakah yang paling panjang dan manakah yang paling pendek.

3. Ulangi langkah 1 sebanyak 10 kali dan simpan di C2-C10, lalu hitung ada berapa selang kepercayaan yang memuat mean $=0$ ? Ulangi kegiatan ini untuk selang kepercayaan $90 \%, 80 \%$ dan $75 \%$.

\section{Membuat Selang Kepercayaan (1- $\alpha)$ untuk mean jika $\sigma$ tidak diketahui.}

1. Buatlah selang kepercayaan $95 \%$ dari data $\mathrm{C} 1$ dengan perintah: Stat/Basic Statistic/1-sample t (dengan memilih level 95\%). 


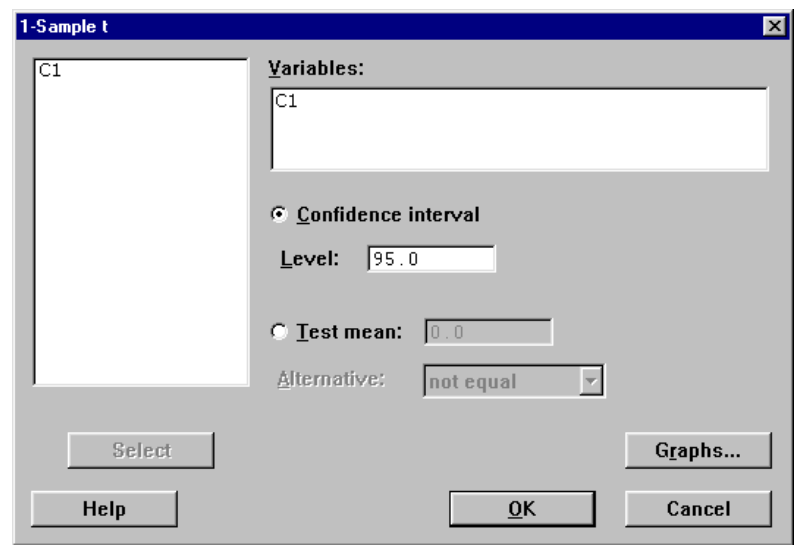

2. Buatlah selang kepercayaan $90 \%, 80 \%$, dan $75 \%$ untuk $\mathrm{C} 1$, lalu bandingkan panjang selang kepercayaan tersebut, manakah yang paling panjang dan manakah yang paling pendek.

3. Ulangi langkah 1 sebanyak 10 kali dan simpan di C2-C10, lalu hitung ada berapa selang kepercayaan yang memuat mean $=0$ ? Ulangi kegiatan ini untuk selang kepercayaan $90 \%, 80 \%$ dan $75 \%$.

\section{Tugas:}

Bandingkan hasil pengamatan I dan II! Apakah ada perbedaan yang cukup menonjol? Beri penjelasan. 
MODUL 7

\section{UJI HIPOTESA UNTUK MEAN SUATU POPULASI}

\section{TUJUAN PRAKTIKUM:}

Mahasiswa/i dapat memahami pengujian hipotesa untuk suatu parameter populasi dengan menggunakan uji-Z dan uji-T untuk satu sampel dalam memutuskan apakah hipotesanya ditolak atau tidak ditolak.

Secara umum, statistika inferensi terdiri atas dua bagian yaitu penaksiran parameter dan pengujian hipotesa. Penaksiran parameter digunakan untuk menaksir besar parameter (taksiran titik) atau menentukan interval yang memuat parameter populasi. Kemudian ditetapkan sebuah hipotesa dari parameter populasi itu lalu diuji berdasarkan sampel dengan keputusan apakah hipotesa tersebut ditolak atau tidak ditolak.

Hipotesa yang mungkin terjadi untuk pengujian mean suatu populasi adalah:
a. $\mathrm{H}_{0}: \mu=\mu_{0} \quad$ vs $\quad \mathrm{H}_{1}: \mu \neq \mu_{0}$
b. $\mathrm{H}_{0}: \mu \leq \mu_{0} \quad$ vs $\quad \mathrm{H}_{1}: \mu>\mu_{0}$
c. $\mathrm{H}_{0}: \mu \geq \mu_{0} \quad$ vs $\quad \mathrm{H}_{1}: \mu<\mu_{0}$

Cara menentukan $\mathrm{H}_{0}$ ditolak atau tidak ditolak:

1. Cari pada tabel (distribusi normal atau distribusi t) nilai kritis $\alpha$ yang diminta. Jika nilai ( $\mathrm{Z}$ atau $\mathrm{t}$ ) pada hasil keluaran minitab berada pada daerah penolakan maka $\mathrm{H}_{0}$ ditolak dan sebaliknya.

2. Dari nilai $\mathrm{P}$ pada hasil keluaran minitab, jika $\alpha>\mathrm{P}$, maka $\mathrm{H}_{0}$ ditolak dan sebaliknya.

\section{Uji-z untuk satu sampel}

\section{Diketahui data:}

$\begin{array}{lllllllllllllll}32 & 22 & 21 & 20 & 42 & 43 & 31 & 21 & 10 & 14 & 18 & 15 & 32 & 33 & 39 \\ 27 & 19 & 18 & 22 & 32 & 30 & 20 & 41 & 42 & 34 & 36 & 38 & 40 & 26 & 25\end{array}$

Dan varian $=9$. simpan di C1

\section{Tugas 1:}

Uji $\mathrm{H}_{0}: \mu=\mu_{0}$ vs $\mathrm{H}_{1}: \mu \neq \mu_{0}$ untuk $\mu=30$ dan $\alpha=0,05$.

Perintah: Stat/Basic Statistic/1-sample z/variabel : C1 Test Mean $=30$ 


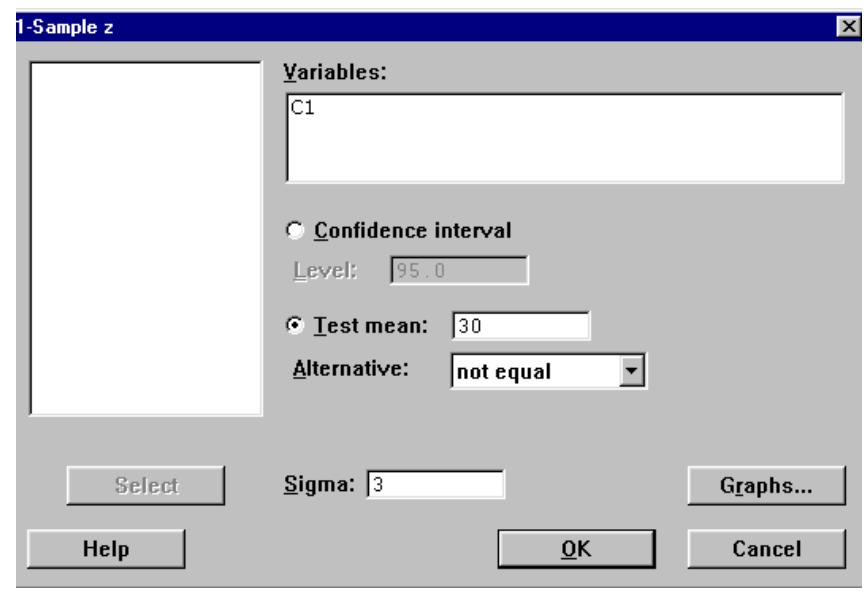

Apakah pada $\alpha=0,05, \mathrm{H}_{0}$ ditolak?

Kemudian lakukan juga pengujian hipotesa untuk $\mathrm{H}_{0}: \mu \leq \mu_{0}$ vs $\mathrm{H}_{1}: \mu>\mu_{0}$ (pada alternative isi: Greater than) dan $\mathrm{H}_{0}: \mu \geq \mu_{0} \mathrm{vs}_{1}: \mu<\mu_{0}$ (pada alternative isi: Less than).

II. Uji-t untuk satu sampel

Pada uji-t sigma ditaksir dengan menggunakan statistik s.

\section{Tugas 2:}

Dari C1 dan tanpa asumsi sigma $=3$, lakukan pengujian hipotesa untuk:

$\mathrm{H}_{0}: \mu=\mu_{0}$ vs $\mathrm{H}_{1}: \mu \neq \mu_{0}, \mathrm{H}_{0}: \mu \leq \mu_{0}$ vs $_{1}: \mu>\mu_{0}, \mathrm{H}_{0}: \mu \geq \mu_{0}$ vs $_{1}: \mu<\mu_{0}$ untuk $\mu=30$ dan $\alpha=0,05$.

Perintah: Stat/Basic Statistic/1-sample t/variabel : C1 Test Mean $=30$

Apakah pada $\alpha=0,05, \mathrm{H}_{0}$ ditolak?

\section{Tugas 3:}

Buatlah 50 sampel acak dari distribusi normal dengan mean $=0$ dan varians $=1$. Simpan data di kolom data C2. lakukan kegiatan seperti tugas 1 dan 2 dengan $\mu=30 \alpha=0,05$.

\section{Tugas 4:}

Buatlah 100 sampel acak dari distribusi normal dengan mean=0 dan varians $=4$. Simpan data di kolom data C3. lakukan kegiatan seperti tugas 1 dan 2 dengan $\mu=30$ $\alpha=0,10$.

\section{Tugas 5:}

Buatlah 1000 sampel acak dari distribusi normal dengan mean=0 dan varians $=16$. Simpan data di kolom data C4. lakukan kegiatan seperti tugas 1 dan 2 dengan $\mu=30$ $\alpha=0,10$.

\section{Tugas 6:}

Beri komentar, pendapat, analisa dan kesimpulan dari setiap kegiatan. 


\section{MODUL 8}

\section{UJI-T UNTUK DUA SAMPEL}

\section{TUJUAN PRAKTIKUM:}

Mahasiswa/i dapat memahami pengujian hipotesa untuk parameter populasi berdasarkan dua buah sampel.

Diberikan kasus sebagai berikut:

Sekelompok pendidik percaya bahwa metoda baru berupa aktivitas tambahan membaca di kelas dapat meningkatkan kemampuan membaca siswa. Kemampuan baca tersebut diukur dengan uji yang disebut Degree of Reading Power (DRP). Untuk membuktikan hal itu, dilakukan kegiatan terhadap dua kelompok sampel siswa.

Sampel $1: 25$ siswa dilibatkan dalam aktivitas baru ini selama 10 minggu

Sampel 2 : 26 siswa mengikuti kurikulum lama.

Setelah 10 minggu, masing-masing siswa diukur skor DRP-nya.

Diperoleh data sebagai berikut:

Sampel 1 (disimpan pada kolom C1):

$\begin{array}{lllllllllllll}24 & 43 & 58 & 70 & 43 & 49 & 61 & 44 & 67 & 49 & 53 & 56 & 59 \\ 52 & 62 & 54 & 57 & 33 & 46 & 43 & 57 & 57 & 56 & 86 & 67 & \end{array}$

Sampel 2 (disimpan pada kolom C2):

$\begin{array}{lllllllllllll}42 & 43 & 55 & 26 & 62 & 37 & 33 & 41 & 19 & 54 & 20 & 85 & 46 \\ 10 & 17 & 60 & 53 & 42 & 37 & 42 & 55 & 28 & 48 & 23 & 21 & 18\end{array}$

\section{Tugas 1:}

1. Buat descriptive statistics untuk sampel 1 dan 2 , lalu analisa perbedaannya antara kedua sampel dan beri kesimpulan dari setiap fungsi statistiknya.

2. Buat Boxplot untuk sampel 1 dan sampel 2. Analisa dan beri kesimpulan.

Hipotesis yang diuji:

$\mathrm{H}_{0}: \mu=\mu_{0} \quad$ vs $\quad \mathrm{H}_{1}: \mu \neq \mu_{0}$

\section{Tugas 2:}

Apakah pada $\alpha=5 \%$ cukup bukti untuk mengatakan bahwa metoda tersebut ada pengaruhnya terhadap tingkat DRP?

Perintah: Stat/Basic Statistics/2-sample t/Sample in different columns (First: C1, Second: C2); Alternative: Not equal; confidence level 0.95; klik assume equal variance.

Tuliskan hasil keluaran Minitab ini pada kertas laporan Anda! Analisa dan beri kesimpulan. 


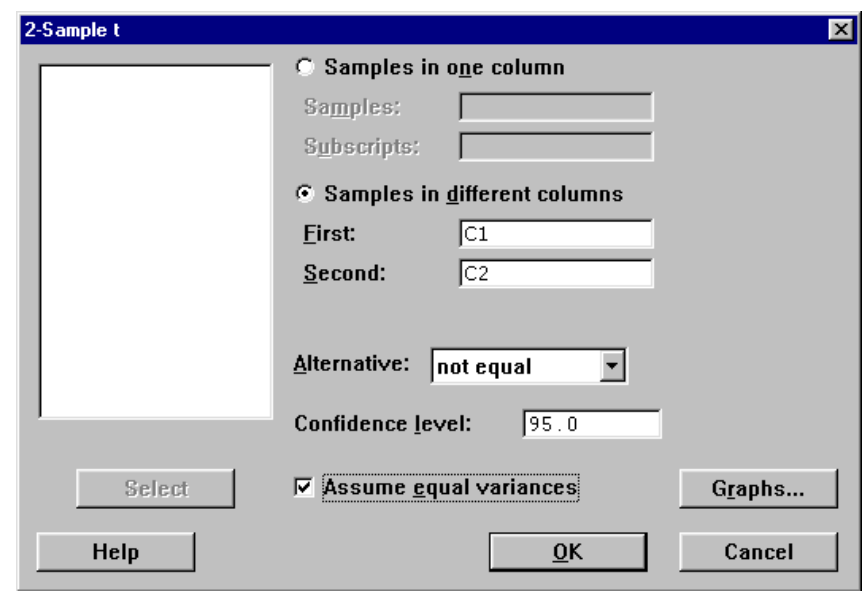

Dari hasil keluaran Minitab, jika $\alpha>\mathrm{P}$ maka dapat dikatakan bahwa cukup alasan untuk mengatakan bahwa metoda baru memberikan pengaruh kepada kemampuan membaca siswa. Alasan ini juga dapat diperkuat dengan melihat nilai mean pada sampel 1 dan sampel 2 yang tidak sama.

\section{Tugas 3:}

1. Apakah untuk kasus di atas pengaruhnya baik? (meningkatkan skor DRP)

2. Rumuskan pasangan hipotesis yang sesuai untuk kasus ini. (pada perintah Minitab Anda atur alternativenya; apakah less than atau greater than)

3. Lakukan pengujian seperti pada tugas 2 .

\section{Tugas 4:}

1. Lakukan pengujian dengan menggunakan asumsi varian menjadi tidak sama. Kemudian lakukan kegiatan seperti pada tugas 2 dan tugas 3.

2. Apakah dengan penggantian asumsi pada varian mengakibatkan perbedaan yang cukup menonjol dari hasil sebelumnya? Beri penjelasan! 


\section{MODUL 9}

\section{REGRESI LINEAR SEDERHANA DAN KORELASI}

\section{TUJUAN PRAKTIKUM:}

Mahasiswa/i dapat menganalisa relasi antara dua variabel melalui metode statistika sederhana yaitu scatter plot, regresi dan korelasi.

Metode Statistika yang paling sederhana untuk melihat hubungan antara dua variabel antara lain:

1. Scatter Plot: untuk melihat secara grafis keterkaitan antara dua variabel

2. Regresi: untuk melihat pengaruh variabel bebas terhadap variabel tidak bebas, apakah variabel bebas tersebut mempengaruhi variabel tidak bebasnya secara signifikan atau tidak.

3. Model regresi linear sederhana dapat dituliskan sebagai : $Y=\alpha+\beta X$

4. Jika nilai $\beta$ tidak nol, maka dapat dikatakan variabel bebas $X$ mempengaruhi variabel tidak bebas Y. X disebut juga Response dan Y disebut juga Predictor

5. Korelasi: Untuk mengukur keterkaitan dua variabel secara linear.

6. Derajat keterkaitan dinyatakan dalam bentuk koefisien korelasi (r). Nilai $r$ terletak di antara -1 dan +1 . Jika $r$ mendekati 1 maka terdapat hubungan keterkaitan yang kuat secara linear yang berbanding lurus antara dua variabel $\mathrm{X}$ dan Y. Jika $\mathrm{r}$ mendekati -1 , maka terdapat hubungan keterkaitan yang kuat secara linear yang berbanding terbalik antara dua variabel $\mathrm{X}$ dan $\mathrm{Y}$. Jika $\mathrm{r}$ mendekati nol, maka kedua variabel $\mathrm{X}$ dan $\mathrm{Y}$ tidak memiliki hubungan secara linear.

Diberikan data-data sebagai berikut:

$\begin{array}{lllllllllll}\text { C1 : } & 67 & 69 & 76 & 79 & 81 & 85 & 89 & 95 & 98 & 99 \\ \text { C2 : } & 10 & 16 & 23 & 25 & 28 & 35 & 39 & 41 & 43 & 47\end{array}$

Gunakan C1 sebagai Response dan C2 sebagai Predictor

Tugas 1:

Apakah $\mathrm{C} 1$ dan $\mathrm{C} 2$ berhubungan secara grafis? Jika ya, hubungan apakah yang terjadi?

Perintah: Graph/Character Graphs/Scatter Plot

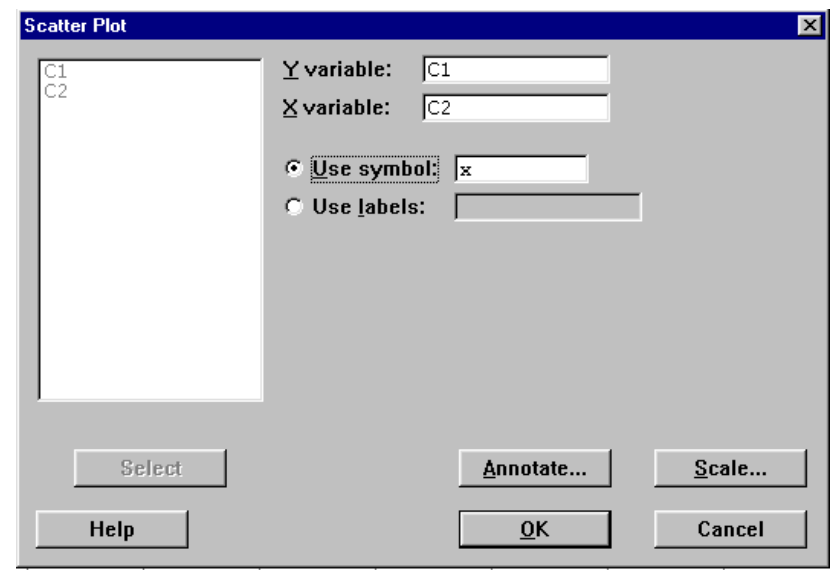




\section{Character Plot}

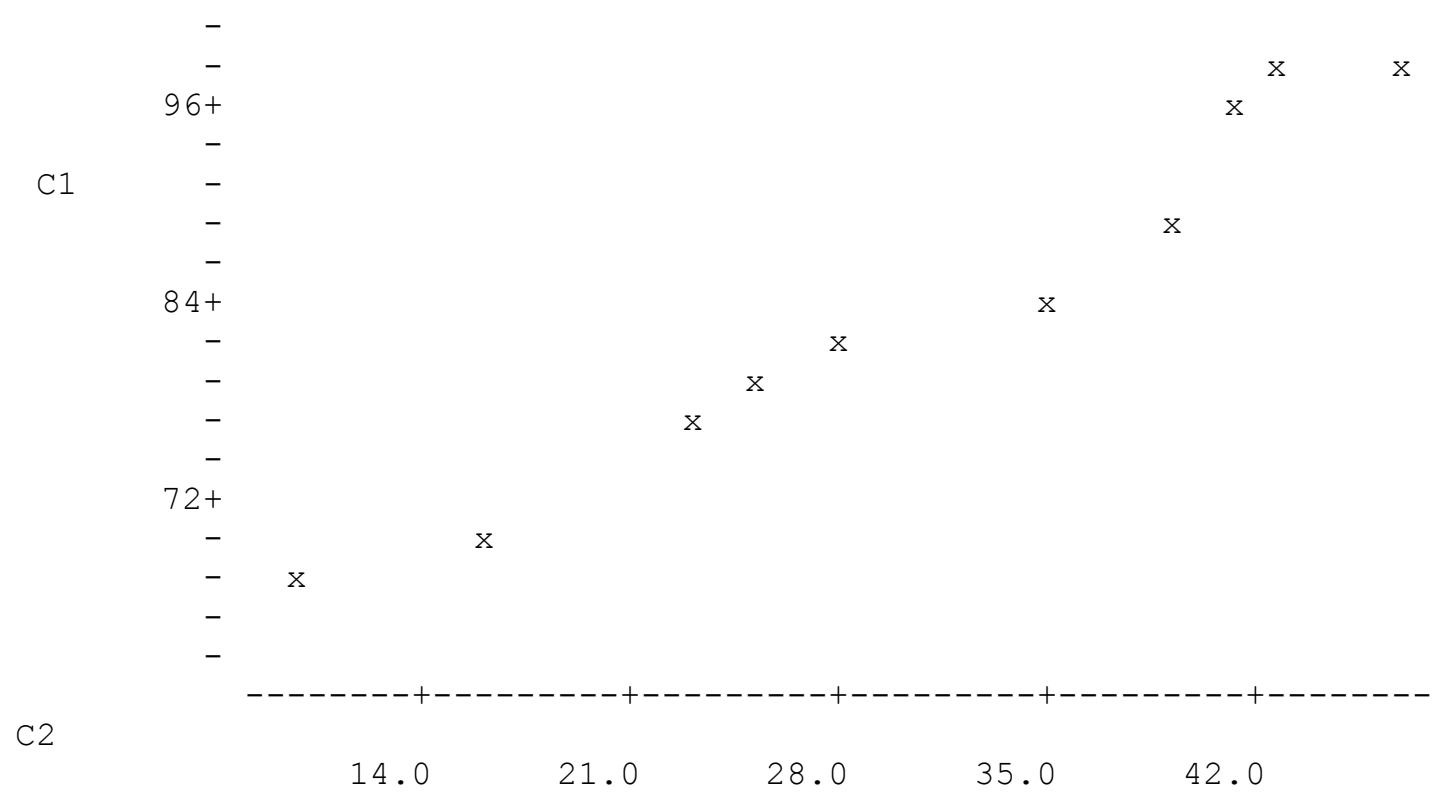

Tugas 2:

Dari data di atas, buatlah model regresi linearnya.

Perintah: Stat/Regression/regression

Apakah responsenya mempengaruhi predictornya secara signifikan?

Untuk memperkuat argumen Anda, ujilah nilai P pada koefisien response dengan $\alpha=$ $5 \%$, jika $\alpha<\mathrm{P}$, maka dapat dikatakan response mempengaruhi koefisien predictornya secara signifikan.

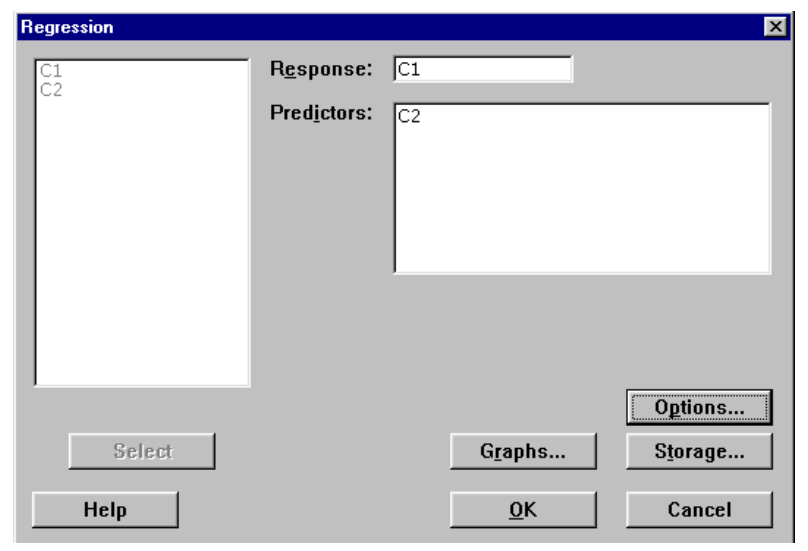

Tugas 3:

Dari data-data di atas, hitunglah korelasi antara response dan predictornya.

Perintah: Stat/Basic Statistics/Correlation

Apakah terdapat hubungan keterkaitan yang kuat secara linear antara response dan predictornya? 


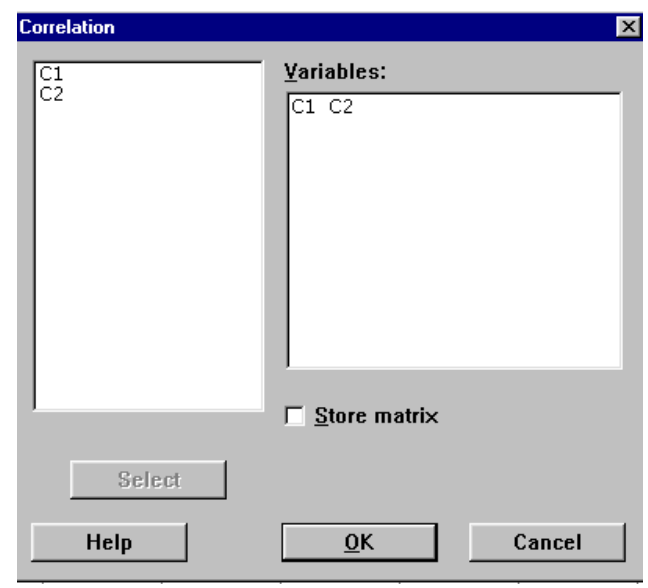

Tugas 4:

Akan dilihat hubungan keterkaitan antara faktor usia dengan kemampuan daya ingat seseorang.

$\begin{array}{lcc}\text { Data } & \text { Usia } & \text { Daya Ingat } \\ 1 & 28 & 90 \\ 2 & 22 & 90 \\ 3 & 39 & 81 \\ 4 & 34 & 86 \\ 5 & 43 & 76 \\ 6 & 72 & 42 \\ 7 & 51 & 70 \\ 8 & 85 & 30 \\ 9 & 47 & 74 \\ 10 & 66 & 65\end{array}$

a. Buatlah plot dari data tersebut di atas dengan usia sebagai sumbu $\mathrm{x}$ dan kemampuan daya ingat seseorang sebagai sumbu y

b. Apakah dari plot tersebut terdapat keterkaitan secara grafis antara kedua variabel? Apakah keterkaitan positif atau negatif.

c. Hitung koefisien korelasinya, kesimpulan apa yang Anda peroleh?

d. Apakah faktor usia mempengaruhi kemampuan daya ingat seseorang? (gunakan $\alpha=5 \%$ ).

e. Dengan menggunakan model regresi yang telah Anda peroleh pada D, perkirakanlah kemampuan daya ingat yang dimiliki oleh seseorang yang berusia 70 tahun.

Tugas 5:

Diberikan data-data sebagai berikut:

$\begin{array}{llllllllllll}\mathrm{X}: & -6 & -3 & -2 & 0 & 1 & 3 & 4 & 6 & 7 & 8 & 10 \\ \mathrm{Y}: & 36 & 9 & 4 & 0 & 1 & 9 & 16 & 36 & 49 & 64 & 100\end{array}$
a. Buatlah plot dari X dan Y tersebut.
b. Apakah ada kaitan antara $\mathrm{X}$ dan $\mathrm{Y}$ ? Jelaskan
c. Hitung koefisien korelasinya
d. Apakah terdapat perbedaan yang cukup menonjol dari hasil yang diperoleh pada b dan c. Jelaskan!


MODUL 10

\section{REGRESI BERGANDA}

TUJUAN PRAKTIKUM:

Mahasiswa/i dapat menganalisa relasi antara dua atau lebih variabel bebas dengan variabel tidak bebasnya.

Metode statistika yang digunakan untuk mengetahui pengaruh antara dua variabel bebas atau lebih dengan variabel tidak bebasnya dinamakan metode regresi berganda.

Model : $Y_{\mathrm{i}}=\alpha_{0}+\alpha_{1} X_{1 \mathrm{i}}+\alpha_{2} \mathrm{X}_{2 \mathrm{i}}+\ldots+\alpha_{\mathrm{n}} \mathrm{X}_{\mathrm{ni}}+\varepsilon_{\mathrm{i}}$

Misal diketahui data:

$\begin{array}{llllll}\text { C1 : } & 550 & 570 & 525 & 670 & 490 \\ \text { C2 : } & 3.2 & 2.7 & 2.5 & 3.4 & 2.2 \\ \text { C3 : } & 22 & 27 & 24 & 28 & 23\end{array}$

Tugas 1:

Tampilkan regresi hasil keluaran Minitabnya dengan menggunakan C2 dan C3 sebagai Predictor. Kemudian tuliskan hasilnya pada kertas laporan Anda!

Analisa hasil keluaran regresi tersebut dan laporkan

Yang dianalisa:

a. Bagaimana bentuk dari model/persamaan regresinya

b. Bagaimana kecocokan model dengan data? Apakah cukup baik? Jelaskan!

c. Berapa nilai R-sq (adj)nya? Dari hasil tersebut, apakah maksudnya?

d. Bagaimana pengaruh Predictor C2 dan C3 terhadap Response C1? Apakah mempunyai pengaruh yang cukup signifikan? Jelaskan! (Gunakan $\alpha=5 \%$ )

e. Apakah konstanta dari model regresi tersebut mempunyai pengaruh yang cukup signifikan terhadap variabel tidak bebasnya?

f. Secara umum pada $\alpha=5 \%$, apakah model ini dapat dikatakan cukup baik jelaskan!

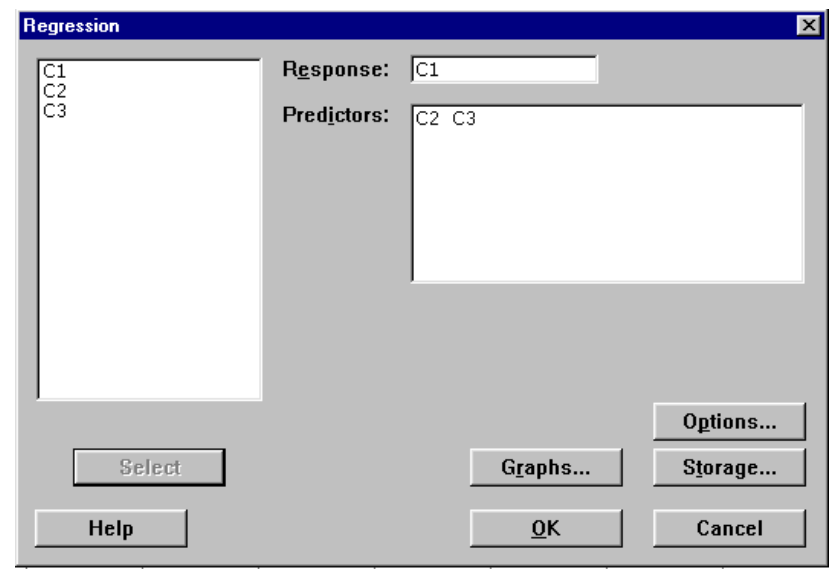




\section{Tugas II}

Diketahui 20 data mengenai berat badan, tinggi badan, dan usia seseorang sebagai berikut:

$\begin{array}{ccc}\text { Berat Badan } & \text { Tinggi Badan } & \text { Usia } \\ 69.0 & 112.5 & 14 \\ 56.5 & 84.0 & 13 \\ 65.3 & 98.0 & 13 \\ 62.8 & 102.5 & 14 \\ 63.5 & 102.5 & 14 \\ 57.3 & 83.0 & 12 \\ 59.8 & 84.5 & 12 \\ 62.5 & 112.5 & 15 \\ 62.5 & 84.0 & 13 \\ 59.0 & 99.5 & 12 \\ 51.3 & 50.5 & 11 \\ 64.3 & 90.0 & 14 \\ 56.3 & 77.0 & 12 \\ 66.5 & 112.0 & 15 \\ 72.0 & 150.0 & 16 \\ 64.8 & 128.0 & 12 \\ 67.0 & 133.0 & 15 \\ 57.5 & 85.0 & 11 \\ 66.5 & 112.0 & 15 \\ 69.9 & 113.0 & 16\end{array}$

1. Tampilkan regresi hasil keluaran minitab dengan menggunakan $\mathrm{C} 2$ dan $\mathrm{C} 3$ sebagai predictor. Kemudian tuliskan hasilnya pada kertas laporan Anda

2. Analisa hasil keluaran regresi tersebut dan laporkan

3. Bagaimana bentuk dari model/persamaan regresinya

4. bagaimana kecocokan model dengan data? Apakah cukup baik? Jelaskan!

5. Berapa nilai R-sq (adj)nya? Dari hasil tersebut, apakah maksudnya?

6. Bagaimana pengaruh Predictor C2 dan C3 terhadap Response C1? Apakah mempunyai pengaruh yang cukup signifikan? Jelaskan! (Gunakan $\alpha=5 \%$

7. Apakah konstanta dari model regresi tersebut mempunyai pengaruh yang cukup signifikan terhadap variabel tidak bebasnya?

8. Secara umum pada $\alpha=5 \%$, apakah model ini dapat dikatakan cukup baik jelaskan!

9. Jika regresi anda cukup baik, perkirakanlah berat badan seseorang yang berusia 18 tahun dan tingginya 130 . 
MODUL 11

\section{ANALISIS VARIANS}

TUJUAN PRAKTIKUM:

Mahasiswa/i dapat memahami analisis variansi satu arah dan dua arah serta mampu menginterpretasikan hasilnya.

\section{$\underline{\text { Analisis Varians Satu Arah }}$}

Kasus: Apakah rata-rata IPK mahasiswa yang mengikuti ekstrakulikuler sepak bola, bola basket, dan hockey berbeda atau tidak $\alpha=5 \%$ ?

Diberikan data sebagai berikut:

Sepak Bola Bola Basket Hockey

C1 $\quad$ C2 $\quad$ C3

$\begin{array}{lll}3.2 & 3.8 & 2.6\end{array}$

$\begin{array}{lll}2.6 & 3.1 & 1.9\end{array}$

$\begin{array}{lll}2.4 & 2.6 & 1.7\end{array}$

$\begin{array}{lll}2.4 & 3.9 & 2.5\end{array}$

$\begin{array}{lll}1.8 & 3.3 & 1.9\end{array}$

Perintah: Stat/Anova/Oneway (unstaced)

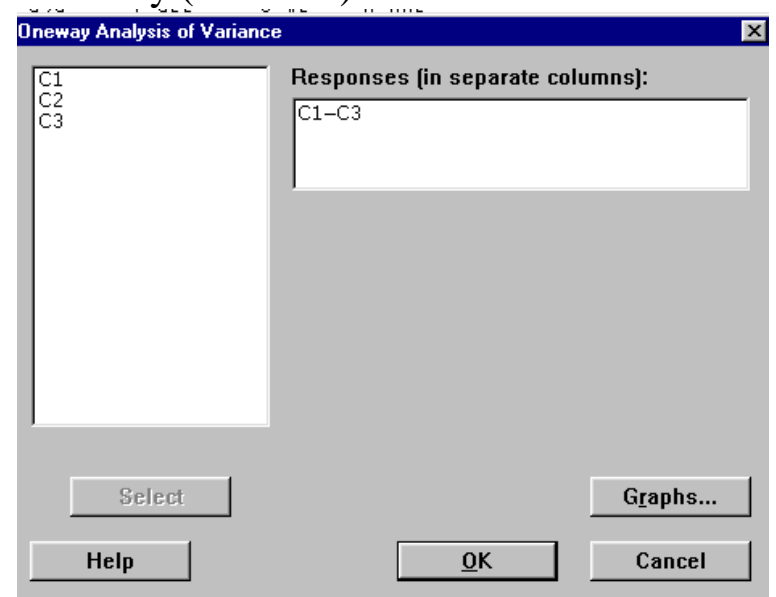

Tugas 1:

a. Tuliskan hasil keluaran Minitab pada kertas laporan Anda! Dan berikan penjelasan secara umum.

b. Rumuskan hipotesisnya! Apakah $\mathrm{H}_{0}$ ditolak atau tidak?

c. Beri kesimpulan dari hasil analisanya.

\section{Analisis Varians Dua Arah}

Kasus: dilakukan pengujian terhadap dua jenis cat tembok untuk bagian luar rumah (enamel dan latex), berapa bulan dapat bertahan. Pengujian dilakukan pada empat lokasi geografis Amerika Serikat yaitu bagian timur, barat, utara dan selatan. Apakah pengaruh lokasi terhadap ketahanan cat berbeda atau tidak pada $\alpha=1 \%$. 
Data ketahanan cat (bulan) tiap merk per daerah geografis adalah sebagai berikut:

\begin{tabular}{|l|l|l|l|l|l|l|l|}
\hline \multicolumn{2}{|c|}{ Utara } & \multicolumn{2}{c|}{ Timur } & \multicolumn{2}{c|}{ Selatan } & \multicolumn{2}{c|}{ Barat } \\
\hline Enamel & Latex & Enamel & Latex & Enamel & Latex & Enamel & Latex \\
\hline 60 & 36 & 54 & 62 & 80 & 68 & 62 & 63 \\
53 & 41 & 63 & 61 & 82 & 72 & 76 & 65 \\
58 & 54 & 62 & 77 & 62 & 71 & 55 & 72 \\
62 & 65 & 71 & 53 & 88 & 82 & 48 & 71 \\
57 & 53 & 76 & 64 & 71 & 86 & 61 & 63 \\
\hline
\end{tabular}

Input data di atas pada Minitab dengan aturan sebagai berikut:

$\mathrm{C} 4$ : berisi seluruh data

C5 : berisi kategori jenis cat ( 0 untuk enamel dan 1 untuk latex)

C6 : berisi kategori lokasi ( 0 untuk utara, 1 untuk timur, 2 untuk selatan dan 3 untuk barat).

Perintah : Stat/Anova/Twoway

Keterangan: response $=\mathrm{C} 4$, Row factor $=\mathrm{c} 5$ (klik display mean) dan column factor $=$ C6 (klik display mean).

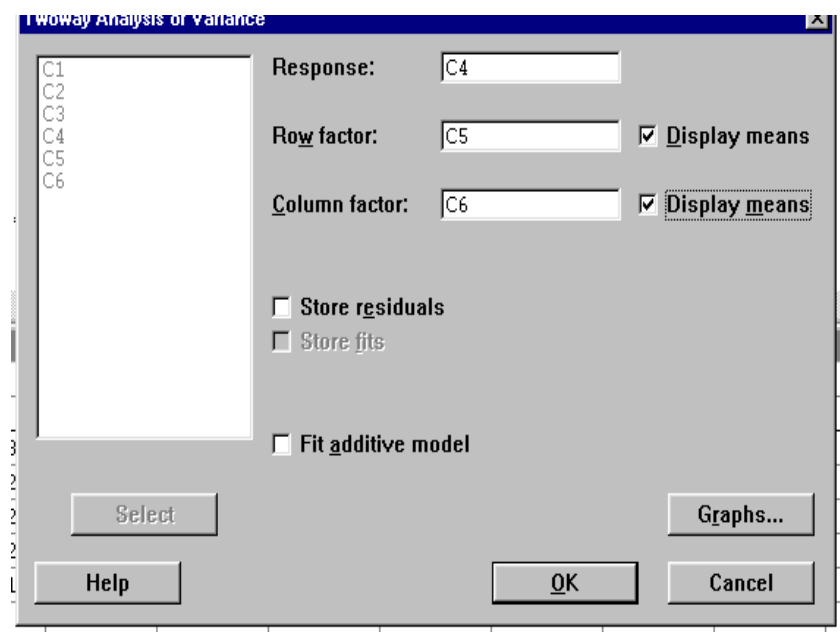

Tugas 2:
a. Tuliskan hasil keluaran Minitab pada kertas laporan Anda! Dan berikan penjelasan secara umum.
b. Berikan kesimpulan dari hasil analisanya. 


\section{MODUL 12}

\section{CHI KUADRAT}

TUJUAN PRAKTIKUM:

Mahasiswa/i dapat menguji dan menganalisa keterkaitan antara dua variabel kategorial.

Untuk menguji keterkaitan antara dua variabel ketegorial digunakan uji khi kuadrat. Data-datanya biasanya disajikan dalam bentuk tabel kontigensi.

Misalkan diberikan tabel kontigensi sebagai berikut:

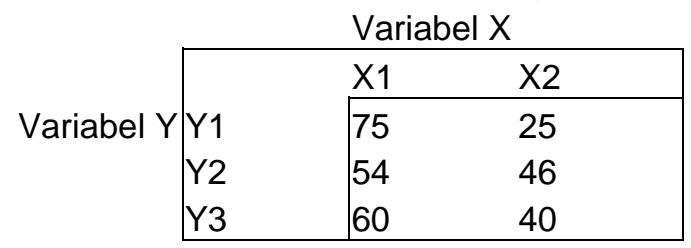

Pada Minitab, isi kolom data $\mathrm{C} 1$ dengan variabel X1 dan kolom C2 dengan variabel $\mathrm{X} 2$

Perintah: Stat/Tables/Chisquare Test (dengan mengisi C1 C2 pada Columns containing the table)

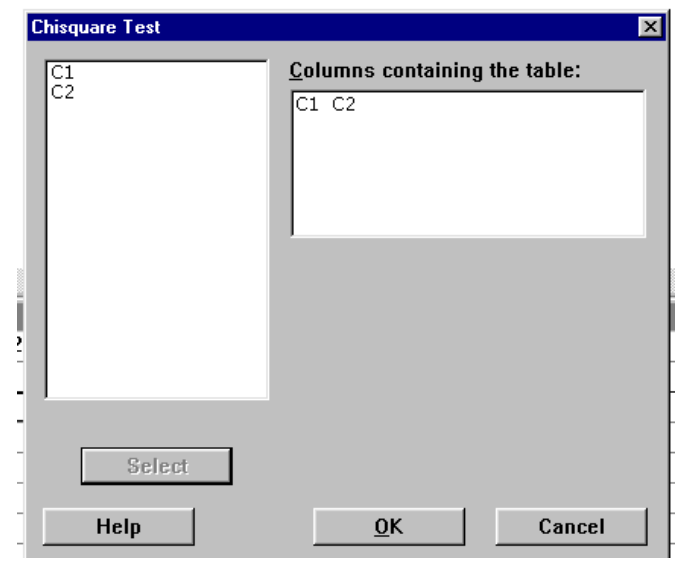

Tugas 1:

a. Tulis hasil keluaran Minitab pada kertas laporan Anda. Beri penjelasan secara umum.

b. Apakah pada $\alpha=5 \%$, variabel $X$ dan Y mempunyai kaitan secara signifikan? Jelaskan!

Tugas 2:

Sebuah perusahaan asuransi mobil ingin mengetahui keterkaitan antara usia nasabah asuransi mobil dengan jumlah premi yang dibayar. Sampel diambil dari 222 nasabah pengemudi sebagai berikut: 


\begin{tabular}{|c|c|c|c|}
\hline & \multicolumn{3}{|c|}{ Jumlah } \\
\hline Usia & $<\$ 50,000$ & $\$ 50,000$ & $>\$ 50,000$ \\
\hline $21-30$ & 16 & 25 & 3 \\
$31-40$ & 23 & 44 & 15 \\
$41-50$ & 16 & 31 & 18 \\
51 atau lebih & 9 & 12 & 11 \\
\hline
\end{tabular}

a. Tulis hasil keluaran Minitab pada kertas laporan Anda. Beri penjelasan secara umum.

b. Pada $\alpha=5 \%$, apakah jumlah premi yang dibayar mempunyai keterkaitan secara signifikan terhadap usia nasabah pengemudi? Jelaskan!

Tugas 3:

Sebuah lembaga perfilman ingin mengetahui keterkaitan antara usia penonton TV dengan jenis film yang ditontonnya. Hasil dari pengambilan sampel diberikan pada data di bawah ini:

\begin{tabular}{|c|c|c|c|}
\hline \multicolumn{4}{|c|}{ Jenis Film } \\
\hline Usia & Dokumenter & Komedi & Misteri \\
\hline $12-20$ & 14 & 9 & 8 \\
$21-29$ & 15 & 14 & 9 \\
$30-38$ & 9 & 21 & 39 \\
$39-47$ & 7 & 22 & 17 \\
48 atau lebih & 6 & 38 & 12 \\
\hline
\end{tabular}

a. Tuliskan hasil keluaran Minitab pada kertas laporan Anda! Beri penjelasan secara umum.

b. Pada $\alpha=5 \%$, apakah jenis film yang dipilih mempunyai keterkaitan secara signifikan terhadap usia penonton? Jelaskan. 